\title{
Artefak Tulang Situs Gua Babi (Kalimantan Selatan): Variasi Tipologis Dan Teknologisnya
}

\section{Bagyo Prasetyo}

Keywords: workshop, industry, assemblage, bones, artifact, cave, settlement, culture, ecofact

\section{How to Cite:}

Prasetyo, B. (1999). Artefak Tulang Situs Gua Babi (Kalimantan Selatan): Variasi Tipologis Dan Teknologisnya. Berkala Arkeologi, 19(1), 40-52. https://doi.org/10.30883/jba.v19i1.791

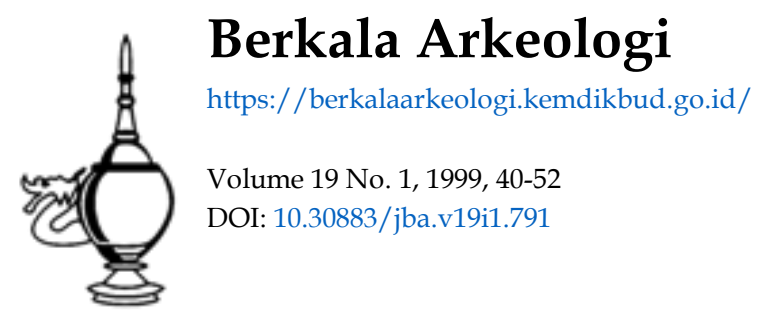

\section{(c) (1) (2) (2)}

This work is licensed under a Creative Commons Attribution-NonCommercial-ShareAlike 4.0 International License. 


\title{
ARTEFAK TULANG SITUS GUA BABI (KALIMANTAN SELATAN): VARIASI TIPOLOGIS DAN TEKNOLOGISNYA
}

\author{
Bagyo Prasetyo \\ (Pusat Penelitian Arkeologi Nasional)
}

\section{A. Pendahuluan \\ 1. Topik Bahasan}

Gua Babi merupakan gabungan antara gua (cave) dan ceruk payung (rock shelter) yang terletak di Bukit Batu Buli, di dalam salah satu gugusan pegunungan karst yang merupakan bagian dari Pegunungan Meratus. Lokasi ini terletak di sebelah barat deretan Gunung Sarempaka, Gunung Lumut dan Gunung Batumanau. Berdasarkan wilayah administratif, termasuk dalam lingkungan Desa Randu, Kecamatan Muara Uya, Kabupaten Tabalong, Provinsi Kalimantan Selatan.

Situs ini pertama kali ditemukan pada tahun 1995 oleh tim Balai Arkeologi Banjarmasin bersama dengan Puslit Arkenas ketika melalukan survei eksploratif di Pegunungan Meratus. Hasil pengamatan muka tanah di halaman gua menunjukkan indikasi adanya data arkeologi yang perlu mendapat penelitian lebih lanjut. Kemudian secara berkesinambungan, Balai Arkeologi Banjarmasin melakukan ekskavasi sejak tahun 1996 sampai 1998. Berdasarkan penelitian tersebut telah menghasilkan sejumlah data arkeologi berupa industri alat batu (serut ujung, serut samping, serut cekung, serut berpunggung tinggi, bor, lancipan bertangkai, bilah dipakai, lancipan, serpih dipakai, batu inti, perkutor dan batu penumbuk, batu pelandas, kapak perimbas, serpih, bilah serta serpihan), artefak tulang, perhiasan serta tembikar (Widianto et.al 1997). Selain data artefaktual, ditemukan juga sisa-sisa fauna, cangkang moluska serta komponen manusia.

Tulisan ini hanya akan membahas tentang artefak tulang ditinjau dari aspek tipologi dan teknologinya. Mengingat penulis hanya mengikuti kegiatan ekskavasi pada tahap I dan II saja, maka data yang dipakai hanya dari hasil penelitian tahun 1996-1997, sedangkan data penelitian tahun 1998 tidak akan disinggung sama sekali.

\section{Tulang: Pemanfaatannya sebagai Artefak}

Artefak tulang (termasuk gigi dan tanduk) banyak dijumpai pada situs-situs gua maupun pada situs terbuka. Penggunaan bahan tulang untuk dimanfaatkan sebagai artefak dimungkinan karena di daerah tersebut jarang dijumpai bahan batu yang cukup 
bagus. Akan tetapi kadangkala pekerjaan yang bersifat ringan maupun agak rumit tidak dapat dikerjakan dengan perkakas dari batu, sehingga diperlukan perkakas dari tulang. Munculnya ide pembuatan/pemanfaatan artefak tulang muncul bersamaan dengan kegiatan berburu binatang. Sumsum sebagai makanan yang lezat dan terdapat di dalam tulang hewan sangat digemari pada waktu itu. Untuk mendapatkannya, maka diperlukan adanya pemecahan tulang dan mungkin secara kebetulan serpihan tulang dipakai untuk pengorek sumsum. Secara tidak sengaja terjadilah teknologi pembuatan artefak tulang, sehingga muncul kemudian ide-ide untuk menciptakan artefak tulang. Pada perkembangan lebih lanjut mulailah dilakukan pemanfaatan dan penyeleksian setiap tulang yang didapat dari hewan buruan untuk dikerjakan sebagai alat (Wirawan 1981:70).

Dalam penelitian arkeologi, artefak tulang ditemukan dalam kurun waktu masa plestosen sampai holosen yang dimasukkan dalam katagori periode paleolitik sampai pre-neolitik bahkan terus berkembang pada masa sekarang di wilayah Indonesia bagian timur (Irian). Tradisi pembuatan alat tulang nampaknya merupakan hal yang bersifat universal, dengan persebarannya mencapai wilayah Eropa Barat dan Asia Daratan. Di Indonesia, situs-situs yang mengandung tradisi alat tulang mendominasi di wilayah karst (gua-gua) serta sebagian kecil dataran sepanjang sungai. Sejauh yang diketahui saat ini persebaran alat tulang terdapat di wilayah Kalimantan Selatan, Jawa Tengah, DIY, Jawa Timur, Sulawesi Selatan, Bali dan Nusa Tenggara Timur serta tradisinya yang masih berkembang di daerah Irian Jaya (Prasetyo belum terbit).

\section{B. Artefak Tulang Gua Babi: Tipologi, Bahan, Teknologi dan Kedudukan dalam Lapisan Budaya}

\section{Tipologi Artefak Tulang Gua Babi}

Sembilan buah kotak ekskavasi yang telah digali pada tahun 1996 dan 1997 ((B12B13, D11-D12, D18, E6-F6, E9-F9, F7-F8, G6-G7, 15, dan K6-L6) telah menunjukkan kuantitas dan kualitas temuan artefak tulang yang cukup beragam. Hasil penelitian terhadap 9 kotak gali hanya menunjukkan 8 kotak (kecuali D18) yang mempunyai kandungan temuan artefak tulang sejumlah 84 buah, dengan jumlah kepadatan yang bervariatif. Adapun jumlah dan persentasi masing-masing temuan artefak tulang pada setiap kotak gali adalah sebagai berikut ini: 
Tabel 1, Kuantitas Temuan Artefak Tulang pada Masing-masing Kotak Gali

\begin{tabular}{||r|l|r|r||}
\hline No & Kotak & \multicolumn{1}{|c|}{ Kuantitas } & Persentasi \\
\hline \hline 1 & B12-B13 & 6 buah & $7.14 \%$ \\
\hline 2 & D11-D12 & 5 buah & $5.95 \%$ \\
\hline 3 & D18 & 0 buah & $0.00 \%$ \\
\hline 4 & E6-F6 & 11 buah & $13.10 \%$ \\
\hline 5 & E9-F9 & 11 buah & $13.10 \%$ \\
\hline 6 & F7-F8 & 19 buah & $22.62 \%$ \\
\hline 7 & G6-G7 & 6 buah & $7.14 \%$ \\
\hline 8 & I5 & 6 buah & $7.14 \%$ \\
\hline 9 & K6-L6 & 20 buah & $23.81 \%$ \\
\hline \hline & Jumlah & 84 buah & $100.00 \%$ \\
\hline
\end{tabular}

Berdasarkan tabel di atas terlihat bahwa kotak K6-L6 merupakan kotak dengan temuan artefak tulang terpadat dibandingkan dengan kotak-kotak lainnya, setelah itu kotak F7-F8, yang kemudian disusul oleh kotak E6-F6 dan E9-F9. Kotak-kotak lainnya tidak begitu banyak ditemukan, bahkan pada kotak D18 tidak ditemukan sama sekali artefak tulang.

Melalui pengamatan tipologis terhadap jenis temuan yang ada, dapat dikelompokkan dalam beberapa tipe, yaitu: tipe a: laneipan; tipe $b$ : jarum; tipe $c$ : spatula; tipe $d$ : alat yang dikerjakan; tipe e perhiasan. Tipe a merupakan jenis temuan terbanyak yaitu 29 buah (34.52\%), kemudian tipe b sebanyak 21 buah ( $25.00 \%)$, tipe c sebanyak 14 buah ( $16.67 \%)$, tipe d sebanyak 17 buah (20.24\%) dan tipe e sebanyak 3 buah (3.57 $\%)$.

\section{Tipe a}

Lancipan adalah jenis alat dengan ujung runcing serta mempunyai penampang yang bervariasi baik cembung-cekung, pipih atau elips, dengan ukuran lebih dari $0.5 \mathrm{~cm}$ tebal/garis tengahnya. Lancipan dengan penampang cembung-cekung atau pipih yang memiliki pangkal lebar dengan ujung runcing dan panjang tidak lebih dari $7.5 \mathrm{~cm}$ dapat digolongkan ke dalam projectil point (Robbins 1981:64). Bentuk-bentuk lancipan masih dikelompokkan lagi dalam beberapa variasi yang meliputi lancipan tunggal monolateral, lancipan tunggal multi lateral dan lancipan ganda monolateral.

Variabel 1: lancipan tunggal monolateral

Adalah bentuk runcingan dengan tajaman satu di bagian distal dan untuk mendapatkan sudut tajaman melalui pengerjaan pada salah satu sisi lateralnya saja. Jenis ini ditemukan sebanyak 21 buah dan merupakan jenis yang paling dominan dibandingkan dengan temuan jenis lainnya. 
Variabel 2: lancipan tunggal multilateral

Merupakan bentuk runcingan dengan tajaman satu di bagian distal dan untuk mendapatkan sudut tajaman melalui pengerjaan pada seluruh sisi lateralnya. Variabel ini hanya ditemukan sebanyak 5 buah.

Variabel 3: lancipan ganda monolateral

Artefak ini mempunyai bentuk tajaman ganda yang terdapat di bagian distal dan proksimal dan untuk mendapatkan sudut tajamannya melalui pengerjaan pada salah satu sisi lateralnya saja. Variabel ini ditemukan sebanyak 3 buah.

\section{Tipe b}

Jarum adalah jenis lancipan dalam bentuk yang lebih kecil (dengan ketebalan/ diameter kurang dari $0.5 \mathrm{~cm}$ ). Jenis ini mempunyai bentuk penampang sama dengan lancipan yaitu bervariasi antara cembung-cekung, pipih atau elips. Jarum hasil penelitian situs Gua Babi dikelompokkan dalam dua variabel, yang meliputi jarum tunggal monolateral dan jarum tunggal multilateral.

Variabel 1: Jarum tunggal monolateral

Adalah bentuk runcingan dengan tajaman satu di bagian distal dan untuk mendapatkan sudut tajaman melalui pengerjaan pada salah satu sisi lateralnya saja. Jenis ini ditemukan sebanyak 18 buah.

Variabel 2: Jarum tunggal multilateral

Merupakan bentuk runcingan dengan tajaman satu di bagian distal dan untuk mendapatkan sudut tajaman melalui pengerjaan pada seluruh sisi lateralnya. Jenis ini ditemukan sebanyak 3 buah.

\section{Tipe c}

Pengertian umum dari spatula adalah alat yang memiliki penampang cembung-cekung atau pipih dan mempunyai permukaan yang lebar. Alat ini memiliki banyak fungsi, antara lain untuk memoles tembikar, meramu makanan, untuk mengerjakan kulit binatang, atau sebagai sendok (Bray dan Trump 1970:215). Bentuk spatula di Situs Gua Babi ini ditunjukkan oleh adanya pemangkasan dan penggosokan pada salah satu permukaannya saja, dan ditemukan dalam jumlah sebanyak 14 buah.

\section{Tipe d}

Kriteria alat yang dikerjakan disini adalah alat yang tidak memiliki kriteria bentuk yang baku, namun bahannya dikerjakan atau dipakai sebagai alat. Alat ini dapat berbentuk persegi, segitiga atau tidak beraturan dengan penampang bervariasi, baik 
cembung-cekung maupun pipih. Jenis artefak ini cukup banyak ditemukan, yaitu berjumlah 17 buah.

Tipe e

Artefak ini lebih berfungsi sebagai perhiasan, bentuk sangat sederhana berupa tulang bercondylus yang dilubangi, dan berfungsi sebagai tempat untuk memasukkan tali. Jenis artefak ini hanya ditemukan sebanyak 3 buah.

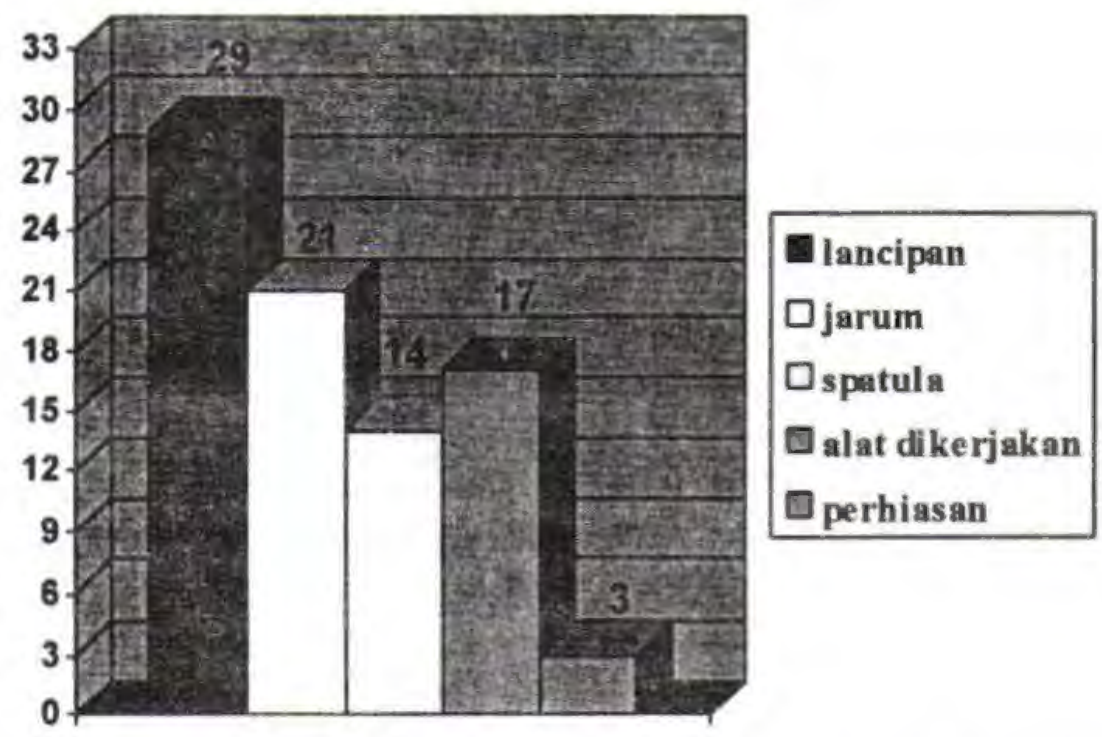

Gambar 1. Grafik Tipologi Artefak Tulang dan Kuantitasnya

Grafik di atas menunjukkan bahwa kuantitas temuan lancipan dan jarum lebih dominan dibandingkan dari tipe temuan lainnya, hal ini membuktikan adanya intensitas pemakaian alat tersebut lebih sering dibandingkan dengan jenis artefak lainnya.

\section{Teknologi}

\section{a. Variabilitas bahan}

Pengamatan berdasarkan bahan pembuatan artefak dikelompokkan dalam beberapa jenis tulang (termasuk gigi) vang meliputi tulang paha, tulang panjang, tulang tengkorak, tulang betis, tulang hasta, tulang humerus, tulang kering, metacarpal, metatarsal, gigi seri dan taring bawah.Tulang paha umumnya diambil dari hewan aves, cervus dan macaca. Tulang panjang diambil dari bagian hewan tragulus, macaca, aves, cervus, sus, serta komponen homo. Tulang tengkorak dari homo, tulang betis diambil dari hewan sus, macaca dan paradoxurus. Tulang hasta, tulang kering 
dan metatarsal merupakan bagian dari hewan aves, dan tulang humerus diambil dari hewan sus dan hystricidae. Adapun metacarpa/ adalah bagian dari hewan cervus. Mengenai taring bawah dan gigi seri merupakan bagian dari hewan sus.

Tulang panjang merupakan tulang yang paling digemari untuk bahan pembuatan artefak tulang. Dari 84 buah artefak tulang yang ditemukan, 38 buah $(45.24 \%)$ diantaranya dibuat dengan bahan dari tulang panjang. Jenis-jenis artefak yang dibuat dengan bahan tulang panjang umumnya berbentuk lancipan (tragulus, macaca, sus, aves dan homo), jarum (tragulus, aves, cervus, dan sus), spatula (sus, aves dan cervus) artefak dikerjakan (homo).

Jenis bahan lain yang juga cukup banyak namun lebih sedikit kuantitasnya dibandingkan dengan tulang panjang adalah tulang hasta sebanyak 12 buah $(14.29 \%)$. Seluruh bahan yang diambil dari tulang hasta merupakan bagian dari hewan aves, yang dibuat hanya dalam bentuk lancipan ganda serta jarum. Yang eukup menarik pada temuan ini adalah adanya tulang tengkorak yang dikerjakan untuk digunakan sebagai alat sebanyak 8 buah $(9.53 \%)$, dan uniknya tulang tengkorak tersebut merupakan komponen dari homo. Jenis tulang lain tidak banyak ditemukan, seperti tulang kering hanya 7 buah $(8.33 \%)$, tulang betis dan tulang paha masing-masing 4 buah $(4.76 \%)$, tulang humerus dan metatarsal masing-masing 3 buah $(3.57 \%)$, metacarpal sebanyak 1 buah (1.19\%). Selain itu ditemukan pula bahan dari gigi seri sebanyak 3 buah $(3.57 \%)$ dan taring bawah sebanyak 1 buah (1.19\%). Tulang kering hanya berasal dari jenis aves dan dibuat sebagai spatula dan lancipan. Tulang betis umumnya dari hewan sus, macaca, dan paradoxurus yang dikerjakan sebagai lancipan dan jarum. Tulang paha merupakan bagian dari aves, cervus dan macaca yang dibentuk sebagai lancipan dan spatula. Tulang humerus diambil dari hewan sus dan hystricidae, yang dibentuk sebagai perhiasan. Tulang metatarsal merupakan bagian dari hewan aves yang dibentuk sebagai lancipan dan spatula, sedangkan metacarpal dari hewan sus yang dibentuk sebagai spatula. Mengenai gigi seri dan taring bawah berasal dari hewan sus dan dikerjakan sebagai lancipan. 


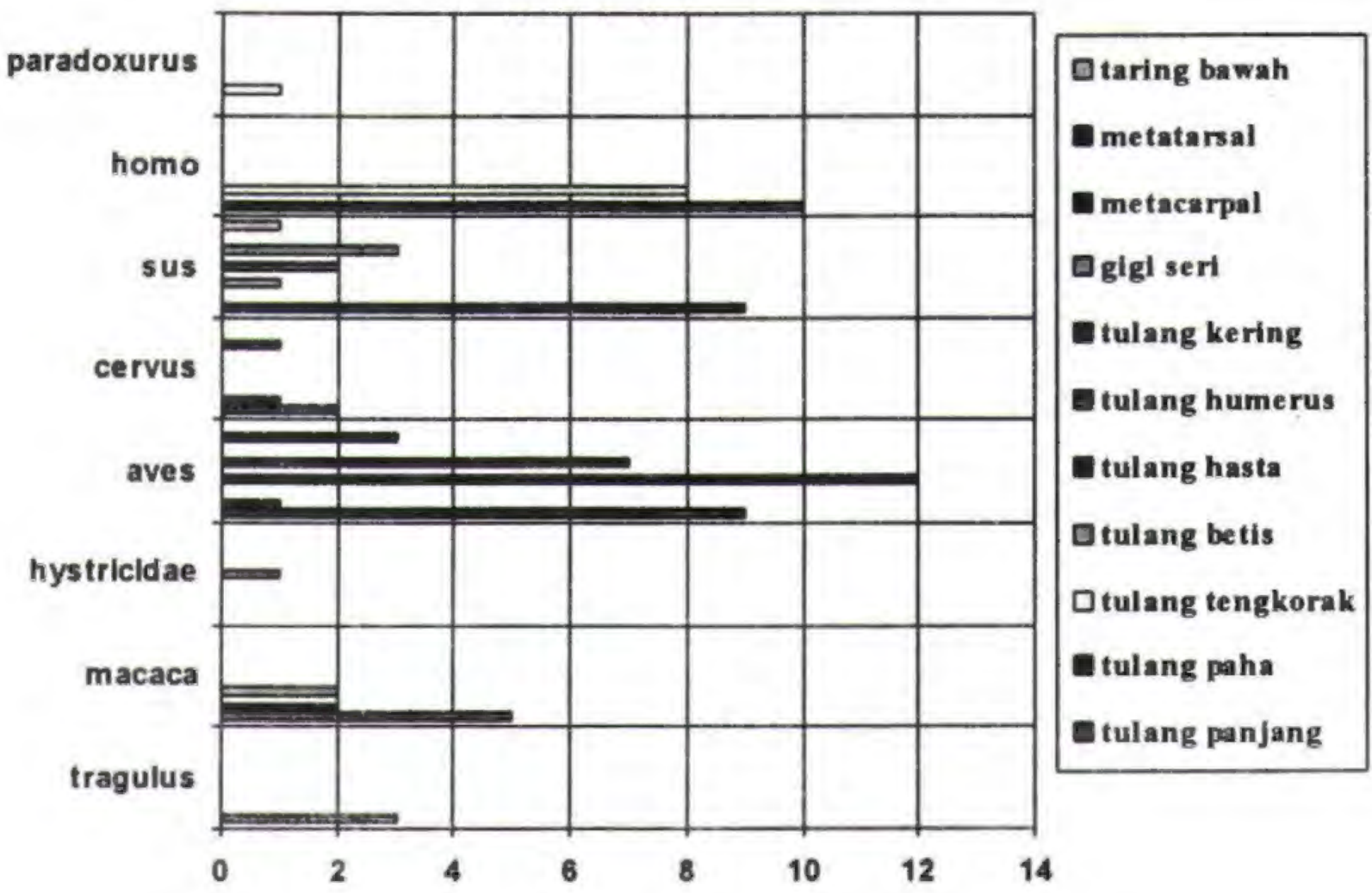

Gambar 2. Grafik Bahan baku pembuatan artefak tulang

\section{b. Teknik pembuatan}

Pengamatan terhadap teknik pembuatan artefak tulang, ada beberapa jenis yang dapat diamati, yaitu:

\section{(1) Teknik Selumbar}

Batang tulang yang sudah dihilangkan bagian epiphysisnya dibelah vertikal pada bagian substantia compacta, sehingga didapatkan bilah tulang yang pipih tanpa adanya sisa canal medullaris. Tahap selanjutnya membentuk artefak sesuai dengan keperluan melalui proses penggosokan. Teknik ini diterapkan untuk bahan baku hewan aves (sebuah), cervus (dua buah) dan homo (sebuah) yang kesemuanya berbentuk artefak spatula terkecuali untuk bahan yang berasal dari homo berujud tulang yang dikerjakan.. Umumnya bahan tersebut diambil dari bagian tulang kering (aves), metacarpal dan tulang paha (cervus) serta tulang panjang (homo).

\section{(2) Teknik Belah}

Sebuah tulang dihilangkan bagian epiphysisnya, baik distal maupun proksimal, supaya tidak mengalami kesulitan pada waktu pembelahan karena masih ada condylusnya. Batang tulang yang merupakan diaphysis kemudian dibelah vertikal. Untuk 
penampang yang cekung melalui pembelahan tepat ditengah canal medullaris, sedangkan penampang yang tidak terlalu cekung pembelahan dilakukan agak ke pinggir mendekati dinding canal medullaris. Penyelesaian selanjutnya sesuai dengan keperluan melalui proses penggosokan. Teknik ini digunakan untuk membentuk artefak jenis lancipan, jarum, spatula dan tulang yang dikerjakan, yang dapat digambarkan pada tabel di bawah ini:

Tabel 2 Variabel bahan baku artefak dari proses pembuatan teknik belah

\begin{tabular}{|c|c|c|c|c|c|c|c|c|c|c|c|c|c|c|c|c|}
\hline \multirow{2}{*}{$\begin{array}{l}\text { Jenis } \\
\text { Hewan }\end{array}$} & \multicolumn{4}{|c|}{ metatarsal } & \multicolumn{4}{|c|}{ tulang kering } & \multicolumn{4}{|c|}{ tulang paha } & \multicolumn{4}{|c|}{ tulang panjang } \\
\hline & 1 & $\mathrm{j}$ & s & td & 1 & $\mathrm{j}$ & s & td & 1 & $\mathrm{j}$ & s & td & 1 & $\mathrm{j}$ & s & td \\
\hline aves & 2 & - & 1 & - & 4 & - & 2 & - & 1 & - & - & - & - & 3 & 3 & - \\
\hline cervus & - & - & - & - & - & - & $=$ & - & - & 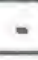 & $=$ & - & - & - & 1 & - \\
\hline homo & $=$ & - & - & - & - & - & $=$ & - & - & - & - & - & 1 & - & - & 7 \\
\hline macaca & - & - & - & - & - & - & - & - & 1 & - & - & - & 1 & - & - & - \\
\hline sus & - & - & - & - & - & $=$ & $=$ & - & $=$ & - & - & - & - & - & 3 & - \\
\hline tragulus & - & - & - & - & $=$ & $=$ & - & - & $=$ & $=$ & - & - & 2 & - & - & - \\
\hline
\end{tabular}

Keterangan:

$\mathrm{l}=$ lancipan $\mathrm{j}=$ jarum $\mathrm{s}=$ spatula $\mathrm{td}=$ tulang dikerjakan

Berdasarkan tabel di atas terlihat bahwa tulang panjang baik aves, cervus, homo, macaca, sus, maupun tragulus lebih dominan dipakai sebagai artefak dibandingkan dengan bagian tulang lainnya. Dari 38 artefak yang dibuat dari tulang panjang, 21 buah diantaranya dikerjakan dengan teknik belah.

\section{(3) Teknik Pecah Celah}

Teknik ini melalui baik pemecahan pada bagian batas antara epiphysis dan diaphysisnya atau tanpa adanya pemecahan. Kemudian dibuat dua celah dengan cara menggores secara longitudinal agak serong ke dalam sehingga menembus canal medullaris. Hasilnya akan memperoleh bentuk batang tulang yang kecil yang selanjutnya digosok sesuai dengan keperluan. Jenis teknik ini diterapkan pada bahan yang diambil dari tulang hewan macaca, paradoxurus, sus, tragulus, aves dan cervis, yang secara ringkas dapat digambarkan pada tabel di bawah ini

Tabel 3 Variabel bahan baku artefak dari proses pembuatan teknik pecah-celah

\begin{tabular}{|l|c|c|c|c|}
\hline \multirow{2}{*}{ Jenis Hewan } & \multicolumn{2}{|c|}{ tulang panjang } & \multicolumn{2}{c|}{ tulang betis } \\
\cline { 2 - 5 } & lancipan & jarum & lancipan & jarum \\
\hline macaca & 4 buah & - & 1 buah & 1 buah \\
\hline paradoxurus & - & - & - & 1 buah \\
\hline sus & 2 buah & 4 buah & 1 buah & - \\
\hline tragulus & - & 1 buah & - & - \\
\hline aves & 2 buah & 1 buah & - & - \\
\hline cervus & - & 1 buah & - & - \\
\hline
\end{tabular}


Data di atas menunjukkan bahwa tulang panjang masih dominan terhadap pembuatan artefak tulang dengan teknik pecah-celah, sebanyak 15 buah dari 38 artefak dari bahan tulang panjang.

\section{(4) Teknik pecah-lubang}

Teknik ini dilakukan dengan cara pemecahan pada bagian batas antara epiphysis dan diaphysisnya di sisi distal, sedangkan sisi proksimal tetap dibiarkan sehingga menunjukkan adanya condylus. Pada bagian condylus yang berbatasan dengan diaphysis dibuat sebuah lubang yang mungkin dipakai untuk memasukkan tali. Teknik ini digunakan untuk membuat perhiasan (bandul kalung?), dan diterapkan pada hewan sus ( 2 buah) dan hystricidae(sebuah) pada bagian tulang humerus.

\section{(5) Teknik pecah-sederhana}

Teknik ini dilakukan dengan cara pemecahan bagian-bagian tertentu sesuai dengan yang dikehendaki. Setelah itu baru dilakukan tahap penyelesaian berupa penggosokan/pengupaman. Teknik ini diterapkan untuk tulang panjang (sebuah) dan fragmen tulang tengkorak (8 buah), yang belum diketahui secara pasti kegunaannya, namun terdapat bekas-bekas pengerjaan maupun bekas-bekas pakainya.

\section{(6) Teknik pangkas}

Teknik ini melalui pemangkasan pada bagian distal, dengan posisi miring sehingga memunculkan bagian canal medullarisnya. Kadang-kadang pemangkasan berlaku juga pada proksimal apabila ingin mendapatkan bentuk tajaman yang ganda. Proses selanjutnya dilakukan melalui penggosokan pada bagian yang sudah dipangkas. Umumnya cara penggosokannya dilakukan secara teliti serta berlaku pada seluruh permukaan tulang, sehingga tidak dapat dilihat lagi sudut-sudut pangkasan. Teknik ini diterapkan pada tulang hasta hewan aves untuk pembuatan lancipan bermata ganda ( 3 buah) dan jarum ( 9 buah). Selain itu juga pada tulang paha hewan macaca untuk membuat spatula, serta gigi seri dan taring bawah sus untuk pembuatan lancipan (4 buah).

\section{Artefak Tulang dalam Lapisan Budaya}

Hasil ekskavasi terhadap halaman Gua menunjukkan adanya 3 buah susunan lapisan budaya yang dapat dijabarkan di bawah ini (Widianto et.al 1997).

\section{Lapisan budaya $A$}

Tersusun oleh lempung pasiran dengan warna coklat kekuningan sampai keabuan, sangat rapuh dan bersifat lepas. Pada lapisan ini terkandung sedikit cangkang moluska ddan kerikil batu gamping. Lapisan ini merupakan lapisan teratas (top soil) yang 
tersisa dari material pengotor batu gamping yang kemudian teracak oleh kegiatan biota dan manusia sekarang.

\section{Lapisan budaya $B$}

Merupakan perlapisan cangkang moluska (shell bed) dengan fragmen utama berupa cangkang gastropoda dengan bagian apex yang terpotong serta tersusun secara acak dengan kontak fragmen yang sangat padat. Perlapisan ini selain tersusun oleh fragmen cangkang moluska juga matriks berupa lempung coklat kemerahan yang hanya mengisi rongga antar cangkang. Rongga dalam cangkang terisi materi mirip lempung pada matriksnya, hanya warnya agak sedikit keabuan. Cangkang maupun matriks pada beberapa tempat dicirikan oleh sisa abu pembakaran, dengan struktur berlapis serta berasosiasi dengan arang. Kidwell (1985) menyatakan bahwa konsentrasi cangkang moluska dalam suatu perlapisan dapat dipakai sebagai dasar dalam menafsirkan proses pembentukannya. Akumulasi cangkang dalam suatu perlapisan belum teraduk (alami) memberikan ciri penumpukan dengan orientasi dan fabrikasi yang seragam, sedangkan hal yang sebaliknya -acak, tanpa orientasi- merupakan proses perlapisan akibat hasil kegiatan manusia. Di dalam perlapisan ini terdapat cukup melimpah alat-alat batu non-masif dari berbagai materi (antara lain basalt, basalt gelasan, obsidian, rijang, gamping kersikan). Selain itu ditemukan pula tulangtulang hewan mikro dan makro serta kadang-kadang terdapat pula komponen manusia. Pada lapisan ini diperoleh data pertanggalan radiokarbon $5.050 \pm 100 \mathrm{BP}$ atau sekitar 5000 tahun yang lalu yang diambil dari sampel arang kotak D11-D12 pada kedalaman $70-80 \mathrm{~cm}$.

\section{Lapisan budaya $C$}

Lapisan ini tersusun dari lempung coklat kemerahan dengan kondisi sangat lapuk, yang merupakan sisa lapukan lanjut dari materi pencampur batugamping yang tidak terlarut. Bagian atas lapisan bercampur dengan fragmen runtuhan batugamping kristalin yang berasal dari endapan speleothems. Fragmen perlapisan pada strata ini masih menunjukkan komponen yang sama dengan strata sebelumnya, hanya sangat berkurang kepadatannya.

Berdasarkan hasil temuan ekskavasi sejumlah 9 kotak (B12-B13, D11-D12, E6-F6, E9-F9, F7-F8, G6-G7, I5, K6-L6 dan D18) menunjukkan bahwa 8 kotak di antaranya (kecuali kotak D18) mengandung temuan artefak tulang dengan berbagai variasi kepadatan pada masing-masing lapisan budaya. Jumlah temuan artefak tulang keseluruhan sebanyak 84 buah yang terbagi dalam tiga lapisan budaya, yaitu 6 buah (7.14\%) pada lapisan budaya A, 74 buah (88.10\%) pada lapisan budaya B, dan 4 buah (4.76\%) pada lapisan budaya $\mathrm{C}$.

Grafik di bawah ini memberikan gambaran lebih jelas tentang persebaran secara vertikal dari masing-masing artefak tulang yang ada. 


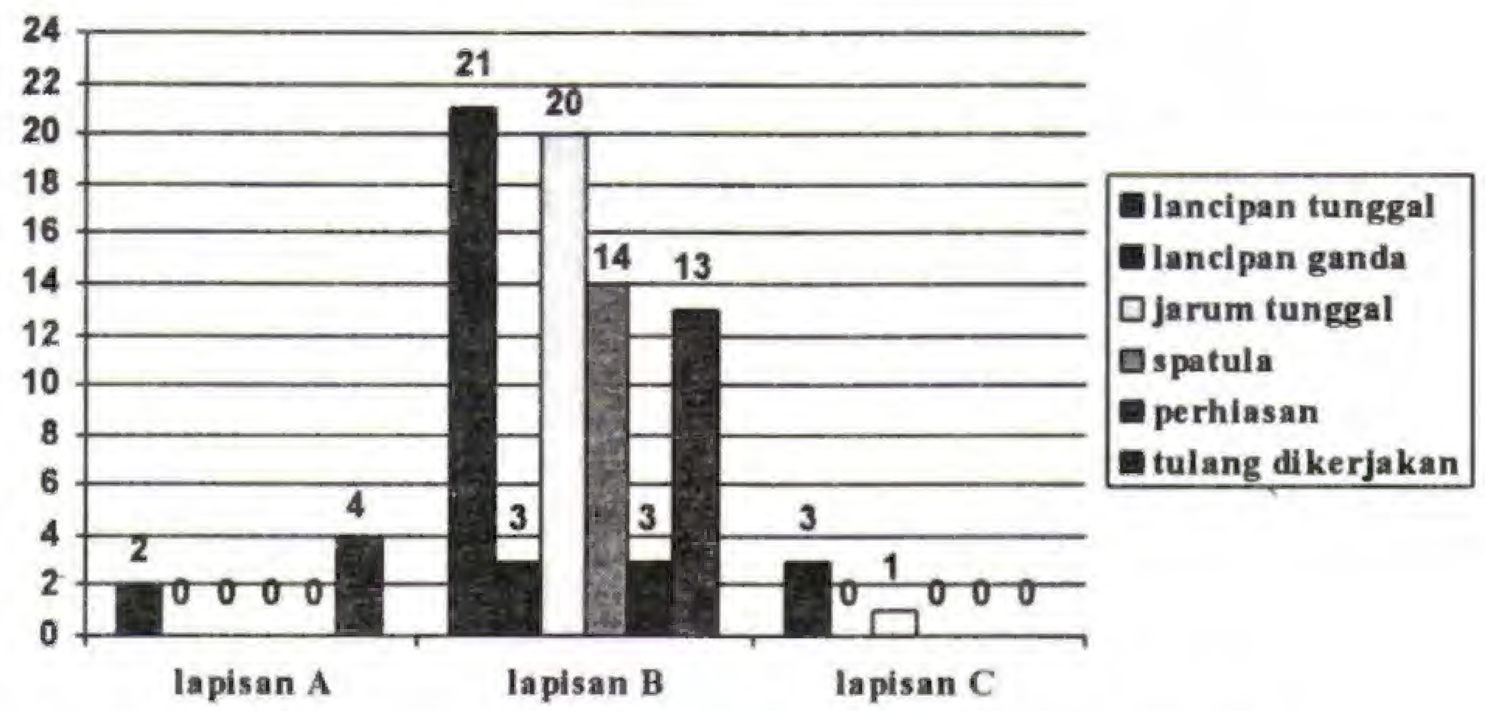

Gambar 3. Grafik Sebaran Jenis Artefak dalam Lapisan Budaya

Pada lapisan budaya A hanya ditemukan sedikit alat lancipan bermata tunggal dan tulang dikerjakan, demikian pula lapisan $\mathrm{C}$ dengan temuan sedikit lancipan dan jarum bermata tunggal. Lain halnya lapisan budaya B yang merupakan tempat dominan dengan kepadatan temuan artefak tulang sebanyak $88.10 \%$ dari seluruh temuan yang ada. Jumlahnya sangat bervariatif, dengan temuan terbanyak adalah lancipan bermata tunggal ( 21 buah) dan jarum bermata tungga ( 20 buah), sedangkan jenis-jenis lain seperti spatula sebanyak 14 buah, tulang dikerjakan sebanyak 13 buah, lancipan bermata ganda serta perhiasan masing-masing sebanyak 3 buah.

\section{Kesimpulan}

Hasil penelitian dari Gua Babi khususnya berdasarkan data artefak tulang menunjukkan bahwa aktivitas pemanfaatan tulang sebagai alat sudah intensif dilakukan. Alat-alat tersebut umumnya digunakan untuk keperluan sehari-hari, data ini didukung oleh adanya eksploitasi secara maksimal terbukti dengan adanya shellbed, serta perapian yang berfungsi untuk berbagai keperluan di antaranya untuk memasak makanan, selain itu juga adanya temuan akumulasi tulang-tulang binatang. Hadimya artefak tulang di Situs Gua Babi tidak akan terlepas pula dari persebaran artefak tulang pada masa pre-neolitik di Indonesia. Tipologi artefak di Situs Gua Babi tidak jauh berbeda dengan yang ditemukan di Jawa, Sulawesi dan Nusa Tenggara Timur, hanya ada beberapa bentuk yang cukup spesifik yang hanya ditemukan di beberapa tempat saja. Bentuk-bentuk spesifik ini terlihat pada jenis lancipan bermata ganda, yang tampaknya hanya ditemukan seperti di Gua Braholo (DIY), gua-gua di daerah Jawa Timur (seperti di Tuban), serta gua-gua di Sulawesi Selatan (seperti Bola 
Batu dan Panganreang Tudea, Leang Burung) (Mulvaney dkk 1970:171). Bentuk seperti ini mengingatkan pada lancipan ujung ganda yang ditemukan di daerah Australia dan sering disebut dengan muduk. Alat ini sebetulnya digunakan untuk menyebut semua perkakas penangkap ikan, tetapi karena yang paling banyak digunakan adalah lancipan ujung ganda, maka muduk juga dipakai untuk menyebut semua lancipan ujung ganda. Lancipan ini ditemukan hampir di seluruh situs di Australia, sehingga timbul istilah mudukian (Mulvaney tt:86). Kenyataan kemudian menunjukkan bahwa muduk mempunyai banyak fungsi, seperti untuk menangkap ikan, perkakas dalam pembuatan pakaian, alat untuk menggores hiasan tembikar dan hiasan hidung pada suku Papua dan Aborigin (Mulvaney 1969:89).

Yang cukup menarik di sini adalah temuan tulang yang dikerjakan yang berfungsi sebagai artefak. Artefak tersebut merupakan bagian dari tengkorak, maupun tulang panjang homo yang jarang sekali ditemukan, kecuali di Situs gua Braholo. Artefak ini diidentifikasikan oleh bentuk fragmen tengkorak yang dipecah dan dibentuk sesuai dengan yang diinginkan (salah satunya bentuk persegi) dan pada sisi-sisinya dilakukan penggosokan. Selain itu juga fragmen tulang panjang yang dibelah, kemudian dilakukan penggosokan pada bagian lateralnya.

\section{Ucapan terimakasih}

Ucapan ini ditujukan kepada Balai Arkeologi Banjarmasin yang telah mengikut-sertakan penulis sebagai partner kerja sejak proses awal penemuan Situs Gua Babi (tahun 1995) sampai dengan penelitian ekskavasi (tahun 1996 dan 1997). 


\section{KEPUSTAKAAN}

Bray, Warwick dan David Trump, 1970. The Penguin Dictionary of Archaeology. Penguin Reference Books.

Kidwell, S.M., 1985. Paleobiological and sedimentological implications of Fossil Concentration, dalam Nature 318. Hlm. 457-460.

Mulvaney, D.J., tt, The Prehistory of the Australian Aborigine, dalam Scientific American 214. Hlm. 84-93.

1969. The Prehistory of Australia. Thames and Hudson. London.

Mulvaney, D.J., dan R.P. Soejono, 1970. The Australian-Indonesian Archaeological Expedition to Sulawesi, dalam Asian Perspective vol. 13. Hlm. 171.

Prasetyo, Bagyo, belum terbit. Persebaran Alat Tulang di Asia Tenggara Daratan maupun Kepulauan, dalam Pertemuan Ilmiah Arkeologi VIII di Yogyakarta tahun 1999. Ikatan Ahli Arkeologi Indonesia.

Robbins, Maurice, 1981. The Amateur Archaeologist's Handbook. New York: Harper \& Row.

Widianto, Harry et.al, 1997. Ekskavasi Situs Gua Babi, Kabupaten Tabalong, Provinsi Kalimantan Selatan, dalam Berita Penelitian Arkeologi Balai Arkeologi Banjarmasin No. 01. Banjarmasin: Pusat Penelitian Arkeologi Nasional Balai Arkeologi Banjarmasin.

Wirawan, 1981. Tulang. Akadoma. 